\title{
Exploring Teachers' Practices in Teaching Robotics Programming in Primary School
}

\author{
Mazlan Muhamad Yusof ${ }^{1}$, Habibah Ab Jalil ${ }^{1}$, Thinagaran Perumal ${ }^{2}$ \\ ${ }^{1}$ Faculty of Educational Studies, Universiti Putra Malaysia, Serdang, Malaysia \\ ${ }^{2}$ Faculty of Computer Science and Information Technology, Universiti Putra Malaysia, Serdang, Malaysia \\ Correspondence: Habibah Ab Jalil, Faculty of Educational Studies, Universiti Putra Malaysia, 43400 UPM Serdang, \\ Selangor, Malaysia. Tel: 603-9769-8210. E-mail: habibahjalil@upm.edu.my
}

\author{
Received: September 3, $2021 \quad$ Accepted: September 28, $2021 \quad$ Online Published: October 15, 2021 \\ doi:10.5539/ass.v17n11p122 URL: https://doi.org/10.5539/ass.v17n11p122
}

\begin{abstract}
Programming and coding are important skills and competencies in the 21 st century. Due to this importance, robotics programming has been introduced in the Malaysian education system since 2013. Robotics is important in education because it could be used to cultivate various skills. Various studies have been conducted on robotics and its applications in education, and proponents of robotics believe that using robotics to teach programming could be impactful and effective in the Malaysian education context. On the other hand, many students think that programming is challenging. Consequently, some questions have arisen, such as the suitable programming language or platform to be used in Malaysian Primary School and the best instructional method. Studies have also examined the existing robotics modules used in the teaching and facilitation (T\&F) process, in which it was found that the current curriculum is focused on introducing robotic programming. In this regard, there is a need to explore the current teaching design, pedagogy, and teachers' practices. Therefore, this study is aimed to explore the teachers' practice in teaching robotics programming as part of the Design and Technology (RBT) subject in Primary School. This study discusses teachers' practices, the issues in robotics programming education, the importance of robotics to education, especially in primary schools, and the robotics kits and programming languages or platforms commonly used in schools. This study is a qualitative case study, and data were collected using in-depth interviews. The findings of this study have produced several key themes, namely: (a) RBT teacher practices (GRBT) in T\&F, (b) Strategies in lesson planning, (c) Challenges and obstacles of T\&F, (d) Use of technology, and (e) Teacher's commitment. These are hoped to help educators, education administrators, and policymakers to understand the implications of robotics teaching in teaching programming.
\end{abstract}

Keywords: robotics programming, robotics education, teachers' practices

\section{Introduction}

The Fourth Industrial Revolution (4IR) era emphasizes the use of supercomputers, smart robots, driverless vehicles, genetic modification, and the development of neurotechnologies to further optimize human-machine functions. 4IR technologies integrate the physical, digital, and biological aspects of human life required to equip future generations to solve problems in the digital world (Schwab et al., 2020). At the same time, the emergence of this revolution brought great challenges due to its impact on various sectors and employment. According to (Bughin et al., 2018), the Mckinsey Global Institute projected that robots and automation would be extensively used in operations, drastically reducing the number of employees. In this regard, by $2030,50 \%$ of companies will rely heavily on automation technology.

In Malaysia, the Fourth Industrial Revolution (4IR) National Policy was launched in 2021 to ensure the country does not fall behind in this revolution. This policy presents the main guideline for all parties involved in formulating strategies and actions that can take opportunities and benefits from the emergence of this revolution. Interestingly, the education sector is outlined as supporting key sectors that focus on new socio-economic growth to the country. One of the policy's focuses is on enhancing teachers' capacity and role based on the need for all teachers to be trained to accept and use 4IR technology in teaching and learning (Unit Perancang Ekonomi, 2021).

In Malaysia, robotics programming has been introduced in the Primary School Standard Curriculum (KSSR) as a 
topic in the Year 5 Design and Technology (RBT) subject. This topic has replaced the programming topic in the Information and Communication Technology subject, which has been repealed. Teachers and students have been actively participating in various robotics activities such as classes, workshops, and competitions at various levels, such as school, district, national and international levels. In fact, the Malaysian robotics team has achieved international success in prestigious competitions such as the World Robotics Olympiad (WRO) (Ibrahim et al., 2014).

Robotics education refers to T\&F activities that use robots to spark students' interest and increase their motivation. A study by (Felicia \& Sharif, 2014) found that robotics is a suitable platform to train students in Science, Technology, Engineering, and Mathematics (STEM) related skills. However, there is a need to identify the best methods and practices in teaching robotics. At the same time, robotics creates good business and investment opportunities for large companies such as Lego which develops robotic educational games such as Lego EV3 Mindstorm, and the Makeblock company that develops Mblock robotic educational tools for learning activities. The increased demands for robotic kits saw Makeblocks products sold in more than 140 countries, with 10 million users in 20,000 schools worldwide.

Robotics education encourages critical thinking and problem-solving skills through designing, building, and programming robots to perform specific tasks using the instructions provided. Several studies have supported the integration of Computer Science into K-12 education. However, students often neglect the elements of Computer Science because they find it complicated. In this regard, we could not ignore the importance of these elements for present and future needs (Sáez-López et al., 2016).

\subsection{Problem Statement}

According to the Ministry of Education (MOE), the number of students taking Science, Technology, Engineering, and Mathematics (STEM) subjects is declining every year. While the role of STEM is closely linked to emerging new jobs and the rapidly growing digital industry, the supply of talent in the field has raised concerns. According to the MOE, in 2018, only 44 percent of Malaysian students took STEM compared to 49 percent in 2012, an average reduction of about 6,000 students each year. This situation will likely cause the country's planning to be hampered to compete in the digital economy era in the coming era (Mohamad Marzuki et al., 2019).

Malaysia's achievement has also lagged in international assessments, such as TIMSS and PISA. While the latest PISA analysis of 2018 (OECD, 2019) showed a slight improvement, this achievement is still falling behind other countries. Meanwhile, Malaysian's performance of TIMSS has continued to decline (Phang et al., 2020).

Despite the various initiatives taken by the MOE to address this issue, such as launching the Malaysia Education Development Plan 2013-2025 (Kementerian Pendididikan, 2013) and introduced the i-THINK mind map for T\&F, its educational achievement is still lacklustre and need to be improved. This is evident through students' low performance in examinations which illustrates the need for appropriate interventions.

As part of the education improvement plan, programming has been included in the Design and Technology (RBT) subject for Year 5. However, the teaching and learning of these skills are still given less attention due to challenges, such as teachers' lack of knowledge and skills (Ling et al., 2017). Programming is deemed as an important element as it is the core of computer science. Teaching programming aims to produce students who can design and develop computer programs by applying computer science's basic concepts and principles. It is an effective way to encourage high-level thinking. As programming requires complex thinking to apply logical rules in problem-solving, novices in this field may experience difficult and complex challenges (Akinola, 2015). Therefore, studies exploring teachers' practices in teaching robotics programming should contribute to new knowledge in this field.

\subsection{Literature Review}

The importance of computer science education for students in grades K-12 is driven by different factors, including economic and technical needs generated by future computer technologies (Cheng et al., 2018). As a result, programming education is actively promoted worldwide to develop human resources to respond to these changes. Programming has been actively supported and taught in schools like the United Kingdom, Finland, and Estonia (Sáez-López et al., 2016).

According to Bers et al. (2014), students could be exposed to robotic technology early through the constructivist approach. The integration of robotics in education provides meaningful experiences to students and helps enhance fine psychomotor development, collaboration, and team spirit. Robotics is one of the ways to interest students in the subject of Mathematics. Robotics is appropriately integrated into problem-solving, equations, accuracy and precision, number and number comparison, measurement, and whole numbers (Silk \& Schunn, 
2008). Programming is the basic concept and principle in the learning of Computer Science. This is an effective method of encouraging high-level thinking. However, it requires the ability to think in a complex way to apply logic and problem-solving concepts, which could be a challenge for people new to programming (Akinola, 2015). If robots are used in programming education, abstract concepts can be implemented visually and physically so that students can understand computer science concepts better (Lawhead et al., 2002).

Since primary school students are at the concrete operational stage in Piaget's hierarchy of cognitive development (Barrouillet, 2015), robotic programming, which involves manipulating specific robots, can be an appropriate method in programming teaching. In this light, concrete experiences using robots can make students more interested in learning (Bers et al., 2014). Furthermore, since the experience accumulated at a young age influences future job choices, it is important to start computer science education in primary school. Robotics embodied in science focuses on the important design, manufacture, and application processes that are important in the IR 4.0 era. Various studies have shown that robotics is an appropriate platform for training skills in STEM (Mariappan et al., 2015). However, the application of robotics in Malaysia to strengthen STEM is still in its infancy, and efforts to expand robotics, especially considering environmental and demographic factors, still need to be explored (Felicia \& Sharif, 2014).

There is a wide gap in the literature as there is a lack of studies on robotic programming module development. There are limited studies that explored the impact of robotic programs in the marketplace, which emphasize the elements of computational thinking. Even though past studies have extensively evaluated consumer perceptions and attitudes towards robotics education, most studies related to robotics learning have been conducted in developed countries. These studies could not be generalized outside the context of the study. Studies exploring teachers' teaching practices in robotics programming and the development of robotics modules, specifically in primary schools, are still lacking in the Malaysian context. Also, there is a lack of studies on how primary school students benefit from computer education (Chen et al., 2017). For example, (Ibrahim et al., 2014) only discussed the potential of robotics in education as a resource material in Malaysia in helping to improve students' high order thinking skill. Meanwhile, (Noh \& Lee, 2020) used the existing robotic programs and activities to evaluate the program's effectiveness on students' computational skills and creativity. Therefore, this study aims to explore teachers' practice in teaching robotics programming as part of the design and technology (RBT) for Year Five students in Primary School. Furthermore, problems and issues in teaching and facilitating robotic programming will be explored and dissected to propose appropriate solutions.

\subsection{Research Questions}

Based on the research objectives, which is to explore teachers' practices in teaching robotic programming in Primary School, two research questions have been formulated, as shown below.

1. What are the teachers' practices in teaching robotics programming as part of the KSSR technology design subject for Year Five students in Primary School? and,

2. How do teachers' practices influence the teaching and facilitation (T\&F) of the robotic programming topic?

\subsection{Conceptual Framework}

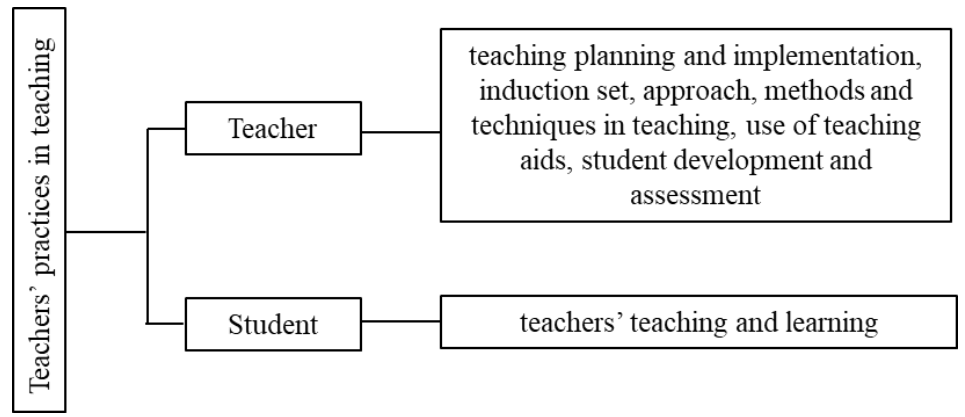

Figure 1. Conceptual Framework of the Study (Adaptation of Research Theory Clark \& Peterson, 1986 and Cobern, 1993 \& al-Ghazali, t.th, and Dunkin \& Biddle, 1974). Source: Jamaludin \& Adam Jaiit (2016)

This study focuses on several aspects, specifically (1) planning and implementation of teaching, (2) use of approaches, methods, and techniques in teaching, (3) use of teaching aids, (4) students' development and assessment of and (5) reinforcement as shown in Figure 1. Teachers' practices in teaching should be guided by teaching planning and implementation, induction set also play a role as a withdrawal of students' interest in 
teachers' practices in teaching. Meanwhile, approach, methods and techniques in teaching are the determinants of good teacher teaching practices plus using appropriate teaching aids. Student assessment cannot be ignored to ensure that all objectives have been achieved.

\section{Research Method}

The qualitative research method has been chosen due to its suitability to the study's objective: to explore teachers' practice in teaching robotics programming as part of the RBT subject for year 5 in Primary School. The case study design was adopted to conduct an empirical investigation on a contemporary phenomenon in its real context using different sources of evidence (Yin, 2003). To be precise, the multi-cases or the multi -fields case study design was adopted as this study involved participants from more than one school. A case study focuses on the context of the subject, individual, group, and program. Hence, the issue is examined in a finite system, such as an environment or a context, in one or more cases. Some researchers refer to case study research as a study strategy, a methodology, or a comprehensive research strategy (Creswell, 2007; Merriam, 1998; Yin, 2003). Case studies are useful for discovering new behaviours, processes, or knowledge we know little about (Mayer, 2001).

\subsection{Research Instrument}

In qualitative research, the researcher acts as the main instrument or tool of data collector. In this regard, an Interview Protocol is needed to ensure that the interviews conducted are directed and the questions do not stray from the main topic of discussion. Hence, the interview protocol was set first before conducting the interviews to collect data. In this study, the draft interview protocol was reviewed by several experts in educational technology and robotics and experts in the field of qualitative research. Corrections and improvements were made to the interview protocol based on the experts' comments.

\subsection{Sampling Procedures}

The informants in this study involved four teachers teaching robotics programming in the RBT subject for Year Five students in Primary School. They were selected using the purposive sampling method based on a set of criteria, namely: (a) their commitment and active involvement in teaching and being coaches for the RBT subject and (b) their qualification, teaching expertise, and experience. To ensure confidentiality, these teachers were labelled as GRBT, as shown in Table 1. This study chose teachers in Pahang and Terengganu as the population of teachers has similar characteristics as teachers in other states. Hence, there are no obstacles to conduct an in-depth investigation of this population.

Table 1. List of Participants

\begin{tabular}{cccc}
\hline Participant & Teaching Experience (Years) & Position & Qualification \\
\hline GRBT1 & 10 & Teacher & Bachelor of Mechanical Engineering \\
GRBT2 & 11 & Teacher & Bachelor of Mechatronic Engineering \\
GRBT3 & 10 & Teacher & Bachelor of Electronic Computer Engineering elektronik komputer \\
GRBT4 & 12 & Teacher & Bachelor of Information Technology \\
\hline
\end{tabular}

National Primary schools were chosen over secondary schools because limited studies have explored this issue in national primary schools. This may be because the Curriculum Development Division, Ministry of Education Malaysia, has just introduced robotics programming as part of the design and technology subject.

Guest et al. (2020) stated that, in general, six to seven interviews are sufficient to cover most of the themes in a homogeneous sample (six interviews to achieve $80 \%$ saturation). On the other hand, for higher saturation (95\%), 11-12 interviews may be required as recommended by the literature, which indicates that, in general, 12 interviews are required to achieve a higher level of saturation. Data collection was carried out after obtaining the informant's consent to be interviewed through a signed consent form. Permission to record the interview session was also obtained from all informants involved.

\subsection{Data Collection}

Data collection was conducted using semi-structured, in-depth interviews with the informants to collect various information and capture their opinions, thoughts, and experiences (Jasmi, 2012). Semi-structured questions were provided instead of open-ended questions to avoid the interview session from straying from the study's objectives. However, questions will be added as appropriate during the interview if required. These semi-structured interviews were conducted online using the Google Meet app. 
The interview sessions were recorded for analytical purposes, as suggested by (Neuman, 2000). Serious attention was given during data recording, and the respondents were encouraged to give detailed explanations. The suitability of the informants' answers was constantly checked. In addition, the transparency of the informants' answers was verified through the mode of delivery and aspects of body language style such as gestures, eyes, and hand movement. Careful preparations were also made to ensure each interview was recorded promptly through notes and audio recordings.

This is in line with (Lebar, 2006), who suggested three basic ways of recording when conducting an interview: making audio recordings, note-taking during the interview, and writing observations right after the interview session. Verbatim transcription was conducted for each recording made. The interview was transcribed in detail, and information such as the interview date, time, and duration were recorded. The transcription was made with care and took a long time to ensure that the results were accurate, and no data was leaked.

\subsection{Credibility}

Validity and reliability in qualitative research attribute to data credibility. They can be verified using several strategies, including member check, audit trail, and external audit. Carpenter (2008) recommended expert review because it illustrates some of the core values of qualitative research related to accurate representation, leveraging participants' knowledge and experience, and reducing data imbalances in research.

\subsection{Data Analysis}

According to (Creswell, 2018), qualitative research data analysis involves preparing and managing data in the form of text transcription, audio, or photographic transcripts. First, excessive data needs to be filtered and cleaned up to produce the most relevant data for the study. Next, it has to go through a coding process based on a set theme. Finally, the data is presented in attractive and effective forms, such as a table, diagrams, and appropriate descriptions.

Data encoding was done to facilitate the analysis process. Systematic coding would produce structured data and can avoid the duplication of the same data. The main source of textual data was transcripts obtained from data collected during the interviews. Transcripts are generated through the transcription process of "converting audiotape records or field notes into text data" (Creswell, 2018).

The first phase involves preparing the data for analysis. First, the audio-recorded interviews were translated verbatim using a form to illustrate discourse units and the interview script. Next, the data were read several times to derive the gist of the source, categorize the main points, and coding them into their sections. Topics and patterns from previous studies discussed in the literature review act as a guide during the initial reading of the transcript

Themes and subthemes relevant to the study questions were determined based on the interview data. Coding is "the process of segmenting and labelling text to form broad descriptions and themes in data" (Creswell, 2018). Coding allows researchers to identify and extract descriptions, themes, topics, or issues more systematically. The descriptions were then transferred to a coding template by arranging the obtained descriptions according to the order of the study questions. Continuous categorization and coding were performed until all five sets of transcriptions were analysed.

Experts were consulted to validate themes and subthemes based on the main ideas in each segment to ensure consistency in interpreting, categorizing, and coding the transcripts. As this study required knowledge of specific terms and a basic understanding of robotic programming, two experts were approached to evaluate the codes and check the accuracy of the initial coding for the discussion.

\section{Results and Findings}

Based on the interview data from the study's informants, four main themes formed the basis of the discussion of this study's findings, as shown in Table 2.

Table 2. Theme and subthemes

\begin{tabular}{lll}
\hline THEME & CODE & SUBTHEME \\
\hline RBT Teachers' (GRBT) T\&F Practices & \multirow{2}{*}{ AG } & $\begin{array}{l}\text { a) Objective Setting } \\
\text { b) T\&F activities }\end{array}$ \\
\hline Strategies in Lesson Planning & & c) Assessment and Evaluation \\
\hline
\end{tabular}




\begin{tabular}{lll}
\hline Challenges and Hindrance in T\&F & $\mathrm{CH}$ & $\begin{array}{l}\text { a) Skills and knowledge } \\
\text { b) Equipment and Facilities }\end{array}$ \\
\hline Use of Technology & $\mathrm{PT}$ & a) Technology Utilisation \\
\hline Teachers' Commitment & KG & $\begin{array}{l}\text { a) High commitment } \\
\text { b) External support. }\end{array}$ \\
\hline
\end{tabular}

\subsection{RBT Teachers'(GRBT) T\&F Practices}

To answer the first research question, 'what are the teachers' practices in teaching robotics programming as part of the KSSR technology design subject for Year Five students in Primary School? , it was found there are several theme and subthemes under GRBT T\&F practice, strategy in lesson planning-, strategy in lesson planning , challenges and hindrance in $T \& F$ and use of technology, which are objective setting, $T \& F$ activities, evaluation, problem based learning, project-based learning, skills and knowledge, equipment and facilities, technology utilisation, high commitment and external support.

\subsubsection{Objectives Setting}

The study found that most RBT teachers have determined the lesson objectives in T\&F based on the Primary School Standard Curriculum (KSSR) Revision 2017, specifically the Curriculum and Assessment Standard Document (DSKP) for Year 5 Design and Technology subject. Design It is stated that "students need to produce a program of choice and iteration control structure through algorithms with pseudocode method or flow chart based on the situation, detect errors and make improvements." The setting of the lesson objectives is also stated in the lesson plan. GRBT1 verified that:

"Ok, for the fifth year programming learning objective, there is a lot. Only by generating an idea of the control structure of choice, the student can construct three main structures: algorithms, pseudocodes, and flow charts, especially according to a given situation. Second, students can construct coding blocks based on algorithms, pseudocodes, and flowcharts. Third, students can produce programs using the coding block programming language according to the steps." - GRBT1

This finding indicates that most RBT teachers have set their teaching goals based on the lesson plan's objectives that correspond to the syllabus set out in the curriculum. Setting the learning objectives is an obligation to a teacher as it is one of the important elements in a teacher's daily teaching record (RPH). RPH are mandatory documents that must be provided by the teacher. Failure to provide the documents can be acted upon by the education department for violating the rules and ethics.

\subsubsection{T\&F Activities}

The results show that the majority of teachers carry out $\mathrm{T} \& \mathrm{~F}$ activities that are appropriate for students to achieve the learning objectives. The T\&F activities mentioned by teachers include dividing students into several groups before assigning the tasks. Most teachers have also considered certain factors before conducting activities. The GRBTs selected the T\&F activities according to the students' level and skills, difficulties and obstacles in performing the activities, and time allocation. The teachers also considered the suggested activities provided in the textbook. For instance, GRBT2 mostly uses activities suggested in the textbook.

"I prioritize the activities suggested in the textbook first. Then added with outdoor activities. For example, assigning students to prepare flowcharts and pedagogues and compile them in a programming language. An example is like entering a timing command and trying to see what output is produced. Exploring the features of programming software."- GRBT2

\subsubsection{Assessment and Reflection}

The findings of the study indicate that the majority of GRBTs conduct assessments in T\&F. Assessment is an important practice that provides useful information about student performance and teacher reflection to make improvements. Assessment is also an important responsibility for teachers to fulfil. GBRT3 assessed students through classroom-based assessment (PBD), as stated below.

"Since we use PBD, the evaluation is staged and all the time. Assessment is based on what students produce. Assessment is easy to do because we look at the projects that students produce"- GRBT3

The PBD has become a very relevant method of assessment in pandemic situations because other assessments such as centralized assessments cannot be carried out. Even if the PBD gives teachers full powers to evaluate students, teachers still evaluate them according to the standards set. 


\subsection{Lesson Planning Strategy}

The interview data showed that the majority of GRBT use several T\&F strategies and approaches, including problem-based learning (PBL) and project-based learning (PjBL). For example, GRBT1 has used PBL by initiating problems that need to be solved.

"I give students a problem, not a problem that is too complex, a problem that is easy for them to solve using flow charts and algorithms"- GRBT1

PBL is learning that begins with a problem, and students build new ideas using support materials, information, and existing knowledge. While PBL is known by various terms, including case-based learning or project-based learning, its sole focus is on providing students with different learning experiences (Bosica et al., 2021).

GRBT2 has used the PjBL approach in T\&F because it is suitable for teaching robotics programming. The interviews showed that even though most teachers understand that the PjBL approach could be integrated with other approaches, they believe that teachers still need to be given an in-depth explanation of PjBL because their knowledge is only limited to a few PjBL elements.

"To complete project assignments given the situation, I use PjBL which organizes collaborative among students".- GRBT2

This finding is in line with Kozinski (2018), which showed that PjBL could make learning more effective than traditional learning in social learning, science, mathematics, and literature. PjBL's holistic approach encompasses providing challenging and complex assignments, interdisciplinary focus, and encouraging cooperative learning. $\mathrm{PjBL}$ also improves the learning of weaker students as it focuses on the collaborative element to help them engaged in lessons by grouping them with higher-skilled peers.

PjBL-based T\&F requires teachers to plan, implement and evaluate projects in real-world situations beyond the classroom. The MOE Education Technology Division has prepared a special handbook to guide educators in implementing this approach (Educational Technology Division, 2006). However, teachers still practice conventional T\&F methods, causing the low application of high-level thinking skills. (Mohamad Nurul Azmi Mat Nor, Nurzatulshima Kamarudin et al., 2017).

\subsection{Challenges and Hindrance in $T \& L$}

Further input on this theme produces two sub-themes, namely knowledge and skills and equipment and facilities.

\subsubsection{Skills and Knowledge}

The majority of teachers agreed that there are hindrances to implementing T\&F to achieve the set objectives. These include mediation language and the programming language. Teachers and students need to be well versed in the specific terms and programming languages to facilitate the T\&F process. According to them, most students find the programming language difficult to understand. Another challenge is the use of non-native or foreign language as mediation language for the programming,

GRBT4 described the challenges in teaching 'loop and repeat.

"when explaining the concept of loop and repeat to my students, I first had to translate the words to their native language, so I need to teach two things, a new language and coding" - GRBT2

Technical skills such as computer literacy (ICT) are also very important in the T\&F of robotic programming topics. In this light, low ICT skills cause T\&F programming to be disrupted and more time-consuming. GRBT3 shared his difficulty in teaching students with low computer literacy

"If students are less proficient in computer use such as clumsy use of mouse and keyboard, will cause T\&F to be disrupted".- GRBT3

According to teachers, students' skills, such as computational thinking skills, are still low. This situation hinders the efforts to achieve learning objectives in RBT subjects. This situation was explained in a systematic literature review conducted by Mohd Kusnan et al. (2020), which involved 19 studies on computational thinking in the Malaysian context. The education department is working on organising various courses, seminars to help teachers improve their skills in this field. In fact, studies to assess the competency of teachers before formulating modules to be used in teacher training were carried out.

\subsubsection{Equipment and Facilities}

Limited access to equipment and facilities is also an obstacle in pursuing effective T\&F of robotic programming. The majority of teachers stated the lack of teaching aids such as robotic sets and appropriate modules caused 
teachers to use only simulated or virtual robot alternatives.

"Students have to share robots... if one robot is shared by a group of 5-6 students, it's ok.. but here one robot is shared by one class; thus, the lesson is less effective".- GRBT3

The expensive price of robotic sets creates an obstacle for teachers and schools to provide for all students. Hence, students need to share the robots in some schools. The use of physical robots is better than simulated and virtual robots in teaching robotics programming because they create real-world experiences that are more interesting and fun. In this regard, physical robots give a more positive impact on students. Multi-party cooperation is needed so that learning facilities can be upgraded and expanded such as involvement of parent-teacher associations (PIBG), industries and universities.

\subsection{Technology Utilisation}

From the aspect of technology use, teachers use various technologies and tools recommended by experts among RBT key trainers such as Mblock, Makecode, Microbit, and Scratch platforms in teaching programming topics. In addition, teachers are highly reliant on both online and offline learning portals.

"There are many technologies and platforms, but you have to be good at choosing to suit students, primary school students prefer cartoons, animations, and many colors because Scratch or Microbit is suitable".- GRBT4

Suk Yong (2019) found that well-developed learning portals positively affected students' achievement. However, improve the Design and Technology (RBT) Year 4 subject learning portal. Similarly, the effectiveness of the use of computer graphics as teaching aids in RBT subjects compared to T\&F without the aids (Isa \& Mohd Imam Ma'arof, 2018).

According to the majority of teachers again, students showed high interest in $\mathrm{T} \& \mathrm{~F}$ activities conducted by teachers. They are engaged in earning because of the effective teacher delivery. However, some students consider robotics programming is still difficult if there are no supporting teaching aids such as robotics kits. Nevertheless, students' interest in participating in T\&F activities during RBT is high due to teachers' use of interesting instruction strategies and appropriate aids (Azita Ali \& Normah Zakaria, 2014).

\subsection{Teachers' Commitment}

\subsubsection{High Commitment}

The findings for the second research question, 'How do teachers' practices affecting and influencing the T\&F of the robotic programming topic', show that most teachers are highly committed to conducting T\&F to ensure learning objectives are achieved despite constraints and obstacles. Lack of equipment, for example, does not prevent them from pursuing $\mathrm{T} \& \mathrm{~F}$ as teachers tried to integrate existing technologies.

"I use what I have, there is a motor and line sensor, it's ok to move the robot. There is more budget later can add other sensors".- GRBT3

High job satisfaction is one of the drivers for highly committed teachers. In this light, a positive workplace atmosphere, good relationships with colleagues, and the appreciation given by the organization are linked to individual job satisfaction (Dayangku Rodzianah \& Mohd Izham, 2021). Teachers in Malaysia are known to be among the highest-committed teachers in their careers no matter what situations they are in.

\subsubsection{External Support}

According to the teachers, close ties with external parties such as robotics companies and local universities have helped the T\&F to be carried out. Some universities also loan robotics sets to schools for $T \& F$ and extracurricular activities, such as to participate in robotics workshops and competitions.

"There are outsiders such as the robotics company reading industry who go to schools to help with advisory services. The university also always organizes robotics training and workshops, sometimes given on loan robots".- GRBT3

The teachers added that suitable learning modules could be developed in partnership with external parties like universities to assist teachers in conducting their T\&F more effectively. This is because universities have more access to the required facilities and expertise, they can invite teachers to their university to gain knowledge and experience by attending courses related to robotic programming.

\section{Conclusion}

This study is limited to exploring teachers' practice in teaching robotics programming as part of the RBT subject for Year 5 students. Therefore, future studies could focus on the development of robotic programming teaching 
modules. Other unexplored elements, like students' achievement in this topic, can also be studied. Relevant parties, such as the Curriculum Development Division, Ministry of Education Malaysia, could identify aspects that can be improved and create guidelines for teachers. At the same time, teachers should also take the initiative by exploring appropriate new strategies and technologies that could be applied in their T\&F activities.

The inherent challenge in carrying out this study is that the country is still facing the covid-19 pandemic, which has caused major changes in education (Aucejo et al., 2020). This situation has affected the motivation and emotions of both teachers and students. The home-based learning and teaching (PdPr) approach has become a new normal, different from the traditional approach and poses a big challenge to all parties. Previously, teachers and students could use T\&F facilities in schools, but now they have to find ways to conduct T\&F with the limited facilities at home. Parents also play an important role in providing suitable T\&F equipment and act as facilitators to support their children's learning at home.

This study showed that most teachers use the KSSR 2017 (revision) Year 5 design and technology subject textbook (RBT) as the main reference for their T\&F contents. However, the textbook's programming topic content can be considered too brief and provide only basic knowledge. Thus, there is a need to find other supplementary materials to complement the T\&F activities. Furthermore, there are no teaching guidelines for teachers included. This situation makes it difficult for teachers to deliver comprehensive learning content due to the lack of required information.

This finding is in line with (Zamri Sahaat \& Nurfaradilla, 2020), highlighting the need to create additional modules and tools as teaching aids to facilitate learning in the classroom. These findings imply that the RBT curriculum needs to be further developed and streamlined. Continuous training and courses need to be provided to RBT teachers. Furthermore, more equipment, facilities, teaching aids, and modules must be provided at the school level to overcome the challenges in implementing T\&F of RBT subjects.

This study highlights the need to provide suitable modules to support learning and as guidelines for teachers. This is because the existing learning content is still limited and dependent on external support materials. The findings of this study can be used as a guide and reference for future studies in programming and robotics. Continuous efforts in forming close ties and cooperation between the school with industry players and local universities must be continued for the sake of progress that could benefit students and teachers.

\section{Acknowledgements}

The authors gratefully acknowledge the funding provided by the Malaysian Ministry of Higher Education's Research University Network Grant (UPM/800-4/11/MRUN/2018/5539210); and the support from Innovative Learning Sciences Research Centre of Excellence (INNOVATE), UPM.

\section{References}

Akinola, S. O. (2015). Computer Programming Skill and Gender Difference: An Empirical Study. American Journal of Scientific and Industrial Research, 7(1), 1-6. https://doi.org/10.5251/ajsir.2016.7.1.1.9

Aucejo, E. M., French, J., Ugalde Araya, M. P., \& Zafar, B. (2020). The impact of COVID-19 on student experiences and expectations: Evidence from a survey. Journal of Public Economics, 191, 104271. https://doi.org/10.1016/j.jpubeco.2020.104271

Azita Ali, Normah Zakaria, L. K. (2014). Persepsi Pelajar Dalam Kemahiran Psikomotor Pemasangan Kit Model Kereta Menggunakan Cd Interkatif. Online Journal for TVET Practitioners (Oj-TP), 59(9-10).

Barrouillet, P. (2015). Theories of cognitive development: From Piaget to today. Developmental Review, 38, 1-12. https://doi.org/10.1016/j.dr.2015.07.004

Bers, M. U., Flannery, L., Kazakoff, E. R., \& Sullivan, A. (2014). Computational thinking and tinkering: Exploration of an early childhood robotics curriculum. Computers and Education, 72, 145-157. https://doi.org/10.1016/j.compedu.2013.10.020

Bosica, J., Pyper, J. S., \& MacGregor, S. (2021). Incorporating problem-based learning in a secondary school mathematics preservice teacher education course. Teaching and Teacher Education, 102, 103335. https://doi.org/10.1016/j.tate.2021.103335

Bughin, J., Seong, J., Manyika, J., Chui, M., \& Joshi, R. (2018). McKinsey Global Institute. Modeling the Global Economic Impact of AI | McKinsey, September, 1-61. Retrieved April 3, 2021, from https://www.mckinsey.com/featured-insights/artificial-intelligence/notes-from-the-ai-frontier-modeling-theimpact-of-ai-on-the-world-economy 
Chen, G., Shen, J., Barth-Cohen, L., Jiang, S., Huang, X., \& Eltoukhy, M. (2017). Assessing elementary students' computational thinking in everyday reasoning and robotics programming. Computers and Education, 109, 162-175. https://doi.org/10.1016/j.compedu.2017.03.001

Cheng, Y. W., Sun, P. C., \& Chen, N. S. (2018). The essential applications of educational robot: Requirement analysis from the perspectives of experts, researchers and instructors. Computers and Education, 126(August 2017), 399-416. https://doi.org/10.1016/j.compedu.2018.07.020

Dayangku Rodzianah, A. A., \& Mohd Izham, M. H. (2021). Tahap Amalan Kepimpinan Instruksional Guru Besar dan Hubungannya Dengan Tahap Komitmen Guru. Malaysian Journal of Social Sciences and Humanities (MJSSH), 6(2), 135-151.

Educational Technology Division. (2006). Project-Based Learning Handbook: Educating the Millenial Learner. In Malaysia: Ministry of Education.

Felicia, A., \& Sharif, S. (2014). A Review on Educational Robotics as Assistive Tools for Learning Mathematics and Science. International Journal of Computer Science Trends and Technology, 2(2), 62-84. www.ijcstjournal.org

Guest, G., Namey, E., \& Chen, M. (2020). A simple method to assess and report thematic saturation in qualitative research. PLoS ONE, 15(5), 1-17. https://doi.org/10.1371/journal.pone.0232076

Ibrahim, H., Abu Samah, N., Bilal Ali, M., \& Phang, F. A. (2014). Robotik dalam Pendidikan di Malaysia. 1st International Education Postgraduate Seminar (IEPS 2014), 1-11.

Isa, N. S., \& Mohd Imam Ma'arof, N. N. (2018). Keberkesanan Penggunaan Grafik Berkomputer Sebagai Alat Bahan Bantu Mengajar Dalam Kalangan Pelajar Reka Bentuk Dan Teknologi. Sains Humanika, 10(3-3), 81-87. https://doi.org/10.11113/sh.v10n3-3.1519

Jasmi, K. A. (2012). Metodologi Pengumpulan Data Analisis Kualitatif. Kursus Penyelidikan Kualitatif Siri, 1, $1-14$.

John W Creswell, J. D. C. (2018). Research Design : Qualitative, Quantitative, and Mixed Methods Approaches. SAGE Publications Inc.

Kementerian Pendididikan. (2013). Malaysia Education Blueprint 2013 - 2025. Education, 27, 1-268. Retrieved from http://linkinghub.elsevier.com/retrieve/pii/S0742051X10001435

Lawhead, P. B., Duncan, M. E., Bland, C. G., Goldweber, M., Schep, M., Barnes, D. J., \& Hollingsworth, R. G. (2002). A road map for teaching introductory programming using LEGO@ Mindstorms robots. Proceedings of the Conference on Integrating Technology into Computer Science Education, ITiCSE, 191-201. https://doi.org/10.1145/960568.783002

Lebar, O. (2006). Penyelidikan kualitatif: Pengenalan kepada teori dan metod. Penerbit Universiti Pendidikan Sultan Idris.

Ling, U. L., Saibin, T. C., Labadin, J., \& Aziz, N. A. (2017). Preliminary investigation: Teachers perception on computational thinking concepts. Journal of Telecommunication, Electronic and Computer Engineering, 9(2-9), 23-29.

Mariappan, M., Sing, J. C., \& Nadarajan, M. (2015). A Design Methodology of Programmable Tangible Blocks for Early Childhood Educational Robotic System. Journal of Applied Sciences Research, 11, 17-25.

Mohamad Marzuki, A. H., Mhod Shukri, N., \& Taha, H. (2019). Gaya pengajaran Grasha dalam kalangan pensyarah sains di Kolej Pra-Universiti di Pulau Pinang. Jurnal Pendidikan Sains Dan Matematik Malaysia, 9(2), 16-24. https://doi.org/10.37134/jpsmm.vol9.2.3.2019

Mohamad Nurul Azmi Mat Nor, Nurzatulshima Kamarudin, Umi Kalthom Abdul Manaf, \& Mohd Hazwan Mohd Puad. (2017). Penerapan Kemahiran Berfikir Aras Tinggi (KBAT) dalam Kurikulum Reka Bentuk dan Teknologi (RBT) Sekolah Rendah. International Journal of Education and Training (InjET), 3(2), 1-7.

Mohd Kusnan, R., Tarmuji, N. H., \& Omar, M. K. (2020). Sorotan Literatur Bersistematik: Aktiviti Pemikiran Komputasional dalam Pendidikan di Malaysia. Malaysian Journal of Social Sciences and Humanities (MJSSH), 5(12), 112-122. https://doi.org/10.47405/mjssh.v5i12.581

Neuman. (2000). Social research methods: Qualitative and quantitative approaches (4th ed.). Boston: Allyn\& Bacon.

Noh, J., \& Lee, J. (2020). Effects of robotics programming on the computational thinking and creativity of 
elementary school students. Educational Technology Research and Development, 68(1), 463-484. https://doi.org/10.1007/s11423-019-09708-w

OECD. (2019). Malaysia - Country Note PISA 2018 Results. Programme for International Student Assessment (PISA) Result from PISA 2018, 1-3, 1-10. Retrieved from http://gpseducation.oecd.org/.\%0AQuestions

Phang, F. A., Khamis, N., Nawi, N. D., \& Pusppanathan, J. (2020). TIMSS 2019 Science Grade 8: Where is Malaysia standing? Journal of Engineering Education, 4(2), 37-43.

Sáez-López, J. M., Román-González, M., \& Vázquez-Cano, E. (2016). Visual programming languages integrated across the curriculum in elementary school: A two year case study using "scratch" in five schools. Computers and Education, 97, 129-141. https://doi.org/10.1016/j.compedu.2016.03.003

Sahaat, Z., \& Nurfaradilla. (2020). Cabaran pelaksanaan mata pelajaran Reka Bentuk dan Teknologi sekolah Menengah. Jurnal Pendidikan Malaysia, 45(1(SI)), 51-59.

Silk, E., \& Schunn, C. (2008). Using robotics to teach mathematics: Analysis of a curriculum designed and implemented. ASEE Annual Conference and Exposition, Conference Proceedings. https://doi.org/10.18260/1-2--3764

Suk Yong, E. (2019). Kesan Penggunaan Portal Pembelajaran Pelajar dalam Subjek Reka Bentuk dan Teknologi.

Unit Perancang Ekonomi, J. P. M. (2021). Dasar Revolusi Perindustrian Keempat (4IR) Negara. Unit Perancang Ekonomi, Jabatan Perdana Menteri, Julai.

Zainal, A. H. J. P., \& Jaiit, A. (2016). Amalan guru Pendidikan Islam dalam proses pengajaran di peringkat Sekolah-Sekolah Menengah Negara Brunei Darussalam. Proceedings of the International Conference on Education towards Global Peace 30 November - 01 December 2016 Kulliyyah of Education, International Islamic Education Malaysia, December, 1-15.

\section{Copyrights}

Copyright for this article is retained by the author(s), with first publication rights granted to the journal.

This is an open-access article distributed under the terms and conditions of the Creative Commons Attribution license (http://creativecommons.org/licenses/by/4.0/). 